\title{
Solving an "APpalling" Problem: Social Reformers and THe CAMPAIGN FOR THE Alberta SEXUAL Sterilization ACT, 1928
}

\begin{abstract}
A. NAOMI NIND
In this article, the author examines the campaign leading up to the passage of the Sexual Sterilization Act in Alberta in 1928. The author asserts that the passage of this Act was the result of the influence of a few elite individuals, particularly those involved with the United Farm Women of Alberta social reform movement, and may not have been reflective of widespread favourable public sentiment. While there were serious misgivings regarding the passage of the Sexual Sterilization Act, the legislation was ultimately successful because of the pressing problems of inadequate mental facilities and budgetary constraints. The author discusses the legislation's eventual repeal in 1972 due to public denunciation of eugenic measures, concerns about liability, and the threat posed to individual liberties. This article was the winner of the William Morrow Essay Contest in 1999.

Dans cet article, l'auteur examine la campagne qui a mené à l'adoption de la Sterilization Act (Loi sur la stérilisation) en Alberta en 1928. L'auteur affirme que l'adoption de cette loi était le résultat de l'influence de quelques membres de l'élite, en particulier ceux qui étaient impliqués dans le mouvement de réforme sociale de la United Farm Women of Alberta et qu'elle n'était peutêtre pas représentative de l'opinion publique. Alors que l'adoption de cette loi soulevait de grandes inquiétudes, elle a été adoptée en définitive en raison des problèmes urgents détablissements de soins mentaux inadéquats et de contraintes budgétaires. L'auteur décrit la révocation de la loi en 1972 occasionnée par la dénonciation publique de mesures eugéniques, les questions de responsabilité et la menace à l'égard des libertés individuelles. Cet article a remporté le prix du concours Morrow Essay en 1999.
\end{abstract}

\section{TABLE OF CONTENTS}

I. INTRODUCTION ..................... 537

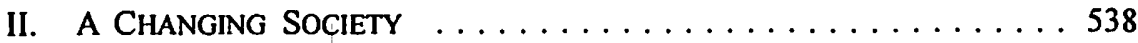

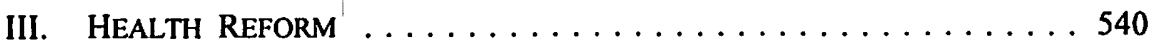

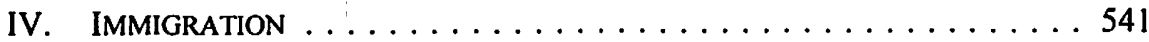

V. REFORMERS AND THE UNITED FARM

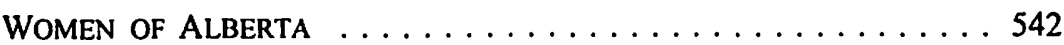

VI. THE CAMPAign for Sterilization IN ALbERTA $\ldots \ldots \ldots \ldots .543$

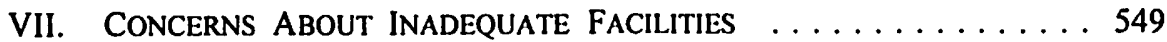

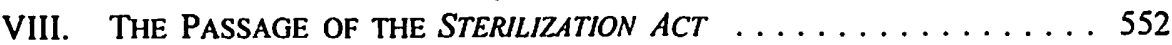

IX. THE QUESTION OF SUPPORT $\ldots \ldots \ldots \ldots \ldots \ldots \ldots \ldots \ldots \ldots 53$

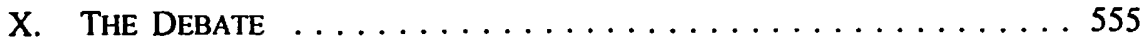

XI. ECONOMIC CONCERNS $\ldots \ldots \ldots \ldots \ldots \ldots \ldots \ldots \ldots \ldots \ldots$

XII. FINAL READING $\ldots \ldots \ldots \ldots \ldots \ldots \ldots \ldots \ldots \ldots \ldots \ldots \ldots \ldots \ldots \ldots \ldots \ldots$

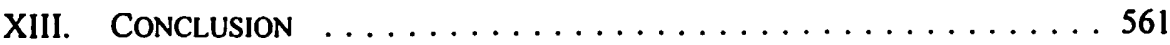

Associate with Emery Jamieson, Edmonton. 


\section{INTRODUCTION}

In 1928 The Sexual Sterilization $A c t^{1}$ was passed by the Alberta provincial government. The first of its kind in Canada, ${ }^{2}$ indeed in the British Commonwealth, the Sterilization Act established a "Eugenics Board" and empowered the Board to authorize the sexual sterilization of those about to be discharged from a mental institution where the Board was unanimously of the opinion "that the patient might safely be discharged if the danger of procreation with its attendant risk of multiplication of the evil by transmission of the disability to progeny were eliminated." ${ }^{3}$ The Sterilization Act was repealed in 1972 on the grounds that the medical and eugenic theories on which it was based were of questionable validity, that its protection for those administering sterilization was considered legally indefensible, and that it offended basic human rights. ${ }^{4}$

The early passage and late repeal of Alberta's Sterilization Act has attracted considerable comment. It has been proposed that it was an illustration of the widespread antagonism harboured towards mental illness in Canada at this time. ${ }^{5}$ Many writers suggest that the Sterilization Act had met with favourable and comprehensive support and attribute its passage to the influence of the United Farm Women of Alberta (UFWA). ${ }^{6}$ But sterilization was not greeted with widespread support in Alberta. That it took the province ten years to enact the legislation reflects the general uncertainty regarding sterilization in this period. Evidence of the reluctance about such measures is also found in the repeated acknowledgement of reformers and legislators that public support was lacking, and in the significant debate the Sterilization Act engendered during its passage. The legislation would not have been enacted but for the joint efforts

The Sexual Sterilization Act, S.A. 1928, c. 37 [hereinafter Sterilization Act].

2 British Columbia was the only other Canadian province to pass such legislation. See $\mathrm{An} A \mathrm{Al}$ Respecting Sexual Sterilization, S.B.C. 1933, c. 59.

3 Supra note $\mathrm{I}$ at s. 5. In its original form the act required the consent of the "inmate" if the board determined the person capable of giving consent. Otherwise, consent of a spouse, parent, or guardian was required.

4 Alberta, Legislative Assembly, Alberta Hansard (31 May 1972) [hereinafter Alberta Hansard] at 58-35 to 58-37. During the years the act was in operation, 2,822 cases were approved for sterilization out of a proposed 4,725. See Law Reform Commission of Canada, Sterilization: Implications for Mentally Retarded and Mentally III Persons (Working Paper No. 24), (Ottawa: Minister of Supply and Services Canada, 1979) at 27. Studies have found the effect of the legislation was discriminatory in nature, disproportionately affecting females, children, ethnic minorities and the impoverished. Ibid. at 42-49. Most analyses of discrimination are based on Christian's work, which also shows that the act was used in a punitive fashion. See T. Christian, "The Mentally III and Human Rights in Alberta: A Study of the Alberta Sexual Sterilization Act" [unpublished, archived at the University of Alberta, Faculty of Law].

S I.H. Clarke, Public Provisions for the Mentally III in Alberta, 1907-1936 (Ph.D. Dissertation, University of Alberta, 1973).

- See for example, A. McLaren, Our Own Master Race (Toronto: McClelland and Stewart, 1990) at 94, 99; F.L. Foster, John E. Brownlee: A Biography (Edmonton: Foster Learning, 1996) at 14749; T.L. Chapman, "Early Eugenics Movement in Western Canada" (1977) 25:4 Alberta History 9 at 15; D.E. Lysne Welfare in Alberla, $1905-1936$ (M.A. Thesis, University of Alberta, 1966), at 99-101; P.V. Collins, The Public Health Policies of the United Farmers of Alberta Government, 1921-1935 (M.A. Thesis, University of Westem Ontario, 1969) at 8-16, 80-85. 
of a small group of prominent reformers. Representatives of the provinces's political, social, and medical elite lobbied for the sterilization of mental defectives in Alberta from 1916 to 1928, focusing their efforts on such organizations as the UFWA. The objective of reformers was realized when sterilization practices were adopted by Alberta legislators in the late 1920 s as a means to solve the pressing problems of budgetary constraints, inadequate facilities, overcrowding, and complaints of abuse in the province's mental institutions in the 1920 s.

This article will examine the sterilization campaign in Alberta, by placing the crusade within the context in Canada of a larger social reform movement to improve the nation's health, education, and morality. In particular, this article will survey the efforts of reformers within the UFWA organization and identify its leaders as a small, elite, close-knit community whose eugenic ideas were inspired by a desire to improve society. The duration of the sterilization campaign and the debate surrounding the Sterilization Act's passage will be presented as evidence of public uncertainty towards sterilization in Alberta at that time. Finally, the identification of sterilization as an antidote to the critical problems of inadequate mental facilities and underfunding will be presented as an explanation for the eventual success of the sterilization campaign in Alberta.

\section{A Changing Society}

An understanding of the success of sterilization legislation in Alberta necessitates an appreciation of the environment in which such a measure gained favour. The years 1901 to 1928 saw a rapid population growth in the area that would become Alberta in 1905. From 1901 to 1926 population figures increased eight-fold from 73,022 in 1901 to 607,599 in $1926 .^{7}$ By 1926 approximately three-fifths of Alberta's population was Canadian-born, with immigrants representing just over 42 percent of the population. ${ }^{8}$ The Anglo-Saxon and Protestant majority of the population ${ }^{9}$ watched anxiously as their province changed, both in nature and in numbers.

Rapid social change caused much anxiety during this period. The social reform movement in Canada first emerged in the east in response to rapid industrialization and urbanization. ${ }^{10}$ The decline of a familiar way of life concerned many groups; the vices of urban living preoccupied business, the church, the government, and social reform groups. Social reform efforts were undertaken by members of the upper and middle classes who shared common concerns about "regeneration and social purity." The expressions of social reform were varied and included such causes as prohibition,

7 Canada Bureau of Statistics, Census of the Prairie Provinces, 1926: Population and Agriculture (Ottawa: King's Printer, 1931) at lii.

* Of these, approximately 16 percent were British-born, 13 percent were U.S.-born, and 13 percent were European/Asian/"other": ibid. at xlii.

- In 1914, Protestants represented 41 percent of the population, while 16 percent were Roman Catholic: J.G. MacGregor, A History of Alberta (Edmonton: Hurtig, 1972) at 206-207.

10 The effects of growth in Toronto and Montreal were especially alarming. See I.R. Dowbiggin, Keeping America Sane: Psychiatry and Eugenics in the United States and Canada, 1880-1940 (New York: Cornell University Press, 1997) at 155. 
health, women's suffrage, education, rural and urban reform, and conservation." Agriculture was seen as the driving force of regional and national progress. This view was articulated by such prominent reformers as W.C. Good, who asserted that "[o]ur future destiny, and national character ... depend on the quality of life that we can maintain in our rural districts." 12 Until the 1920 s, social reform agitation emphasized moral and spiritual improvement and was marked by amateurism. The second phase of social reform saw the rise of professionalism and an emphasis on scientific expertise and management.

Ideas about women's special role, both as mothers and wives, abounded in reform rhetoric. The concept of "separate spheres" was an important ideological influence in the nineteenth and twentieth centuries. Perceived challenges to woman's traditional position in the home as a result of new forms of knowledge and changing methods of production, as well as concerns about urbanization's effect on the deterioration of family and health created renewed emphasis on woman's special role and her proper sphere. The qualities of moral judgement, delicate sensibility, and maternal love were encouraged. With the advent of progressivism, a model of educated motherhood replaced the earlier emphasis on maternal virtues and instincts; the focus was on the needs of the child and the necessity of being prepared for the role of motherhood. Women were encouraged to extend their maternal instincts outside of the home to reform work that would benefit society as a whole. ${ }^{13}$

A contemporary work which chronicles the dire consequences of rural decline is J. MacDougall, Rural Life in Canada: Its Trends and Tasks (Toronto: University of Toronto Press, 1973). For social reform in Canada, see generally R. Cook, The Regenerators: Social Criticism in Late Victorian English Canada (Toronto: University of Toronto Press, 1985); L. Kealey, ed., A Not Unreasonable Claim: Women and Reform in Canada, 1880s-1920s (Toronto: Women's Educational Press, 1979); M. Valverde, The Age of Light, Soap and Water: Moral Reform in English Canada, 1885-1925 (Toronto: McClelland and Stewart, 1991). From a speech to the Empire Club in Toronto, 1916, quoted in R.C. Brown \& R. Cook, eds., Canada, 1896-1921: A Nation Transformed (Toronto: McClelland and Stewart Limited, 1974) at 316 [emphasis in original].

13 S.M. Rothman, Woman's Proper Place: A History of Changing Ideals and Practices, 1870 to the Present (New York: Basic Books, 1978). A poem to inspire potential reformers was published in the 1929 UFWA Convention Report:

Do you wish the world were better?

Let me tell you what to do,

Set a watch upon your actions -

Keep them always straight and true.

Rid your mind of selfish motives,

Let your thoughts be clear and high.

You can make a little Eden

Of the sphere you occupy.

See United Farm Women of Alberta, Reports and Addresses, 1929 [hereinafter UFWA 1929] at 44. 


\section{HEALTh REFORM}

Health was a major pre-occupation of social reformers, especially maternal feminists, who claimed health was the particular domain of women. In 1916, well-known social reformer Nellie McClung declared:

[M]en and women are not alike, because they have their separate spheres [and] we believe woman's voice and woman's point of view must be represented before we can have a humane civilization.... Since the old days when a part of woman's household duty was to brew the herbs, etc., right down to the present it has been part of woman's duty to care for the sick.... To women we leave the great task of the healing and binding .... [I]t is typical; it is women's work."

Lack of medical aid in Alberta was a critical concern in the early twentieth century, particularly in rural areas, where the majority of women were in their child-bearing years or were mothers of young children especially susceptible to disease or at risk of farm accidents. This period witnessed high infant and maternal mortality rates. ${ }^{15}$

Concern about health reached new heights as a result of World War I. In Alberta, as in the rest of Canada, people were shocked at the large number of military recruits pronounced unfit for service. ${ }^{16}$ Anxiety about health was also heightened by the numbers of mentally and physically injured returning soldiers. In addition, a strain was placed on the medical resources of the province as doctors, dentists and nurses headed to war, eliminating services many in the province had only begun to enjoy. ${ }^{17}$ Concern for public health intensified with a widespread and severe epidemic of Spanish

United Farmers of Alberta, Annual Report and Yearbook, 1917 [hereinafter UFA 1917] at 173 and 177. The next year, in her presidential address to the UFWA Convention, Irene Parlby, another prominent social reformer, asserted: "Perhaps we must not look too much for the help of the men in this movement. The bearing of the race, and the care of the race is the woman's job." United Farmers of Alberta, Annual Report and Yearbook, 1918 [hereinafter UFA 1918] at 277. That men subscribed to this maternal feminist argument is evidenced by the comment of the UFA President in 1928: "Farm women take much more interest in community and social affairs than the men; and it is needless to say they handle them much more adroitly and efficiently." United Farmers of Alberta, Minutes of the Annual Convention, 1928 [hereinafter Minutes 1928] at 5. In 1922, 111 maternal deaths were recorded in Alberta, 84 occurring in rural areas, which represented the highest rate in the country. This figure is from H. MacMurchy's Report on Maternal Mortality in Canada, 1928 quoted in C.A. Cavanaugh, In Search of a Useful Life: Irene Maryat Parlby, 1868-1965 (PhD Dissertation, University of Alberta, 1994) at 112-13. In an address to the UFA Convention in 1918, a representative of the Alberta Medical Association, Dr. Stanley, described an "abnormally high" infant mortality in the province of 33 percent during the years 1913-1917: UFA 1918, ibid.

16. In the 1919 annual report of the UFA, the medical inspection of schools was supported by the observation that most recruits pronounced unfit for military service in World War I were rejected because of the results of accident or disease in childhood, which, it was asserted, if treated properly could have been remedied in most cases. It was reported that only one-half of those examined in Canada were "A2" - physically fit. United Farmers of Alberta, Annual Report and Yearbook, 1919 [hereinafter UFA 1919] at 107.

b L.G. Thomas, The Liberal Party in Alberta: A History of Politics in the Province of Alberta, 19051921 (Toronto: University of Toronto Press, 1959) at 155-56. 
influenza in 1918-1919. ${ }^{18}$ During the outbreak, the province recorded more than 30,000 cases of influenza and suffered more casualties than were caused by the war. ${ }^{19}$

\section{IMMIGRATION}

Public concern for the health of the Alberta population led to a focus on the large numbers of immigrants arriving in the province. The differences which existed between the predominantly Anglo-Saxon Protestant population and the various ethnic groups were especially highlighted in urban centres, where increased crime, immorality, and disease were attributed to immigrants. In the early part of the twentieth-century, the process of assimilation was an important part of the reform movement in Canada. A declining birthrate among Anglo-Protestants and the resulting fear that the steady influx of immigrants would overwhelm the native-born and destroy the distinct nature of Canadian society encouraged reformers to commence a program of assimilation to "Canadianize" foreigners and dilute foreign influence. ${ }^{20} \mathrm{~A}$ contemporary comment on the dangers of indiscriminate immigration advocated the weeding-out of undesirables, particularly among European immigrants. ${ }^{21}$ Social reformers urged enhanced entrance standards to ensure a better quality of immigrant. In her address to the Alberta UFWA Convention in 1924, the President of the organization queried:

Viewed from a racial standpoint is it not of prime importance that we subject to the closest scrutiny our immigration regulations?... Do we exercise care that all those seeking admittance shall be required to pass a rigid mental and physical examination? $?^{22}$

Concerns about the threatened decline of Canadian society due to industrialization, immigration, and urbanization coincided with great advances in the medical field. Reformers placed considerable reliance on contemporary medical solutions to major social problems. As well, many social reformers placed great faith in the theories of Charles Darwin and Sir Francis Galton. The theory of eugenics was first promoted in Britain in 1883 by Galton, who advocated the improvement of the human race through selective breeding. Reasoning from Darwin's theory of the survival of the fittest, Galton concluded society's advancement was assured by the propagation of the fit and the elimination of the unfit. ${ }^{23}$ Such eugenic principles were promoted by prominent Alberta reformers, such as the President of the UFWA in 1924:

For ages, the iron rule of the survival of the fittest saw those qualities of strength, endurance, beauty, and intelligence, perpetuated in the race, while Mother Nature, inexorable to the individual, but with true racial beneficence, allowed the inferiors, the misfits, and the degenerates to be "stamped out of

Alberta, Report of the Deparment of Municipal Affairs of the Province of Alberta 1918 (Edmonton: J.W. Jeffrey, King's Printer, 1919) at 6.

Collins, supra note 6 at 5 .

See P. Voisey, "The 'Votes for Women' Movement" (1975) 23:3 Alberia History 10 at 13.

See generally J.S. Woodsworth, Strangers Within Our Gates or Coming Canadians (Toronto: University of Toronto Press, 1972).

United Farmers of Alberta, Minutes of the Annual Convention, 1924 [hereinafter UFA Minutes 1924] at 70.

See Chapman, supra note 6 at 9. 
existence.[sic] Today we have a complete reversal of this procedure. Science, medicine, and philanthropy enable many weaklings to reach maturity, preserve inferiors and degenerates, and take no measures to prevent continuous racial impoverishment. ${ }^{24}$

\section{REFORMERS AND THE UNITED FARM WOMEN OF ALbERTA}

The lobbying of health reformers within the UFWA during the period 1916 to 1928 reflected the health concerns that dominated Alberta during this time. The organization was formed in 1916 as the women's counterpart to the United Farmers of Alberta (UFA). The UFA welcomed the UFWA for political reasons (specifically, they believed it would increase the farm vote in Alberta) as much as for the belief that women's contributions would "smash corruption, purify politics and place the life of the nation on a higher plane."25 Before 1921, the UFWA used the weight of the UFA to bring pressure on the provincial Liberal government for legislative reform, including health reform. The Liberal government needed the UFA's support to consolidate its position with the rural electorate and so a close working relationship between the UFA, UFWA, and the Liberal government existed during this period. ${ }^{26}$

While the UFA and UFWA both lobbied for health reform, it was the UFWA that was more influential. In 1921, members of the UFA formed the majority in the newlyelected Alberta legislature, and the UFA and UFWA organizations continued to urge the government to action. Vital to health reform in this period was the presence of Irene Parlby in the Cabinet of the UFA government. Parlby recognized the influence of the UFWA on provincial governments:

The discussions and actions of this Association have always been regarded with very special interest by whatever government has been in power, and many suggestions with regard to such matters as education or Public Health which have emanated from your Conventions have found their way into legislation or into policies of the Government. 27

Before entering politics, Parlby held the position of President of the UFWA and she continued to influence the organization during her term in government. The influence of prominent reformers in Alberta organizations such as the UFWA, Women's Institutes ${ }^{28}$ the Women's Christian Temperance Union, and the Social Service League was significant. These were men and women whose wealth and occupations allowed

24

Annual Address of the President of the UFWA, Margaret Gunn: UFA Minutes 1924, supra note 22 at 69.

25 P.F. Sharp, The Agrarian Revolt in Western Canada: A Survey Showing American Parallels (New York: Octagon Books, 1971) at 73.

26 Thomas remarked of the period 1909-1921 that: "Before long the UFA Convention had more to say in the determination of the policy of the Liberal government than the provincial legislature." Thomas, supra note 17 at 206. Sce also Lysne, supra note 6 at 63-64, and Collins, supra note 6 at 8-9.

27. United Farm Women of Alberta, Reports and Addresses, 1928 [hereinafter UFWA 1928] at 6.

28 The maternal feminist goals of the Women's Institutes are outlined by $S$. Bosetti in The Rural Women's University: Women's Institutes in Alberla from 1909 to 1940 (M.Ed., University of Alberta, 1983). 
them to devote time to social causes. They were educated and professional members of society, well-read and well-spoken. ${ }^{29}$ The leaders and the majority of the members of these organizations were those whose household labours were lightened by domestic servants and by economic developments which removed traditional work from the home. They were not farmers but residents of urban centres which offered professional work and amenities. Those who resided in cities and rural towns and villages enjoyed a lifestyle distinct from their farming counterparts, and their reform initiatives reflected their different values and experiences. A survey of the membership of "farm women's organizations" such as Women's Institutes and the UFWA reveals that they tended to be townswomen rather than farm women, who did not share the heavy burden of farm work with their families and who had the opportunity and the time to become involved with social reform organizations. ${ }^{30}$

From its inception in 1916, the Alberta UFWA advocated such health reforms as rural hospitals, more nurses, dentists and doctors in rural areas, medical inspection of schoolchildren, certificates of health before marriage, maternity and infant care, venereal disease prevention, first aid instruction, state medicine, travelling clinics, dissemination of health knowledge, birth control, and the segregation and sterilization of the mentally deficient. ${ }^{31}$ In 1936, the President of the UFWA outlined the organizations success in health reform and claimed that, as a result, "no province in the Dominion had better or more advanced health legislation." ${ }^{132}$

\section{The Campaign for Sterilization in Alberta}

Key to the health agenda of Alberta reformers was the belief articulated by UFWA President Margaret Gunn that "with the restoration of physical health, mental health frequently follows." "Sane minds in sane bodies" became their theme. ${ }^{34}$ Reforms

In her study of western Canadian women leaders, Robinson describes them as well-educated, public-spirited, and progressive. Many had experience as teachers, writers, nurses, home economists, and temperance and suffrage leaders. See L.M. Robinson, Agrarian Reformers: Women and the Farm Movement in Alberta, 1909-1925 (M.A. Thesis, University of Calgary, 1979).

The extent to which the Women's Institutes and United Farm Women organizations represented farm women has been questioned by such authors as C.L. Bacchi, Liberation Deferred? The Ideas of the English-Canadian Suffragists, 1877-1918 (Toronto: University of Toronto Press, 1983) at 124-31; P. Rankin, "The Politicization of Ontario Farm Women" in L. Kealey \& J. Sangster, eds., Beyond The Vote: Canadian Women and Politics (Toronto: University of Toronto Press, 1989) at 313-18; and M. Kechnie, "The United Farm Women of Ontario: Developing a Political Consciousness" (1985) 78:77 Ontario History 267 at 271-74. That rural studies require an appreciation of the important differences between farm and non-farm interests is described in B.J. Cooper, "Farm Women: Some Contemporary Themes" (1989) 24:Fall Labour/Le Travail 167 at 168, and N.E.S. Griffiths, Penelope's Web: Some Perceptions of Women in European and Canadian Society (Toronto: Oxford University Press, 1976) at 144.

Sce United Farmers of Alberta, Annual Report and Yearbook, 1917-1921, 1924; United Farmers of Alberta Addresses and Reports Presented to the UFA Convention, 1927-1930, 1933-1934, 19361937, 1939-1941; United Farm Women of Alberta, Reports and Addresses of the Annual Convention, 1927-1930, 1933-1934.

3 M. Gunn, "The Farm Women's Program for 1924" The U.F.A. (19 February 1924) I. 
aimed at combatting mental deficiency included inspecting children, providing maternity care, preventing venereal disease, and requiring health certificates before marriage. ${ }^{35}$ Of all the proposed health reforms, eugenic reforms specifically aimed at the mentally unfit generated the most resistance. Such measures were first advocated by reformers within the UFWA in early 1917 , who proposed that there be segregation of the feebleminded. Although mechanisms for segregation were provided for in The Mental Defectives Act, 1919, ${ }^{36}$ the lack of mental institutions and the repeated calls for segregation into the 1920 s suggest that its provisions were initially rarely used.

Associated with the earliest proposals to deal with the problem of the mentally unfit was the lobby for the ultimate eugenic measure: sterilization. The campaign for sterilization commenced earlier than is described by most commentators, who pinpoint 1921 as the commencement of provincial (and, in particular, UFWA) interest in such a measure. ${ }^{37}$ Eugenic ideas had currency among many of those connected to social reform in the province, including members of the medical and legal professions and members of the government and legislature, who used their social, professional, and academic influence to lobby for sterilization legislation. Such reformers were representative of the predominantly white, Anglo-Saxon, Protestant population of Alberta, who had a firm belief in their natural superiority over other races and classes. Many were inspired amateurs who placed great faith in scientific and medical theories to solve social problems. An analysis of the sterilization campaign, especially in the UFWA, will reveal the extent of reformers' efforts and the inter-connectedness of the reform community.

The first call by reformers within the UFWA for control over the mentally defective occurred at the 1917 Annual Convention:

Whereas, the greatest freedom of action allowed to persons who are feeble minded, or mentally deficient, is not only productive of much crime and immorality, but is a grave menace to future generations;

Therefore, be it resolved: That the Government be asked to introduce legislation for the compulsory segregation of this class of person, both juvenile and adult. ${ }^{38}$

R.B. Gunn, "An Editorial on Education" The U.F.A. (15 April 1922) 1.

In 1918 the province passed The Venereal Diseases Prevention Act, S.A. 1918, c. 50. which allowed for the examination and treatment of any person committed to jail or any other provincial public institutions. The Solemnization of Marriage Act, S.A. 1925, c. 39 [hereinafter the Marriage $A c t$, s. 29 provided that persons who issued marriage licences or who solemnized a marriage knowing or having reason to believe that one or both parties to the marriage was "an idiot or insane or mentally incompetent" were guilty of an offence and subject to a maximum fine of $\$ 500$ or 12 months incarceration. In 1939 the Marriage $A C t$ was amended to require an affidavit from the parties to a marriage declaring non-infection by venereal disease. An Act 10 Amend The Solemnization of Marriage Act, S.A. 1935, c. 51, s. 2.

The Mental Defectives Act, S.A. 1919, c. 21. This act provided for the compulsory institutionalization of mental defectives by caregivers or by the Minister of Health, who could incarcerate notwithstanding refusal by guardians.

McLaren, supra note 6 at 99-100; Dowbiggin, supra note 10 at 179-80; Lysne, supra note 6 at 98101.

UFA 1917, supra note 14 at 143. 
At the UFA Convention held in 1918 , it was reported that the compulsory segregation of the feeble-minded had commenced with the establishment of an institution in Red Deer, and that as soon as finances permitted, work would be undertaken on a larger scale. $^{39}$ At the same conference, two representatives of the Alberta Medical Association, Drs. Lincoln and Stanley, addressed the delegates, advocating the establishment of a separate Department of Health. Dr. Stanley recounted the duties of such a department, which would include the care of the insane whom he described as multiplying in the province at a rate out of proportion. Stanley acknowledged:

[W]e come here to enlist the sympathy and support of a representative gathering of farmers. We realize ... [i]n regard to any reform or advanced movement, particularly in regard to any advanced movement respecting matters of health it is necessary to have behind it a public opinion that will demand. ${ }^{\text {to }}$

While reformers first promoted segregation as a means to "control" mental defectives, they almost immediately hinted at more drastic actions. In her 1919 UFWA Presidential address, Irene Parlby observed that Alberta was starting to deal with the problem of mental defectives by segregating them in mental institutions. However, she then suggested that further steps were necessary:

Public opinion is as yet hardly aroused to the need of action along certain lines. Our part is to help form public sentiment and keep urging on our Department of Health to bring about necessary reforms."

Concern about the rapidly growing numbers of mental defectives resulted in the call to undertake a survey of schools to determine the number of abnormal or feeble-minded children in the province. In 1919 Professor D.G. Revell compiled the "Mental Hygiene Survey of the Province of Alberta" at the request of the Provincial Cabinet to obtain information concerning the mental defective population. ${ }^{42}$ The survey hinted that sterilization was one measure the province could use "to prevent an increase of its abnormal population." 43 Issues considered in the survey included:

The problem of mental deficiency in public schools and steps that have been taken to deal with the situation; Mental abnormality as a factor in delinquency; The relationship that exists between mental abnormality and such social problems as illegitimacy, prostitution, and dependency; The effect of immigration on the problem of mental abnormality in Alberta; and Urgent hygiene needs in Alberta

39)

4)

UFA 1918, supra note 14 at 75.

Ibid. at 145 .

The 1918 UFA Annual Report related that a school for feeble-minded children had been opened by the government in south Edmonton: ibid. at 90 . The next year, it was reported that this home was temporary, housing 35 children and that the government had acquired a site approximately five miles from Edmonton for the building of a permanent institution to accommodate 2,000 patients. See UFA 1919 , supra note 16 at 84.

2 This report was published in 1921 under the auspices of the Canadian National Committee for Mental Hygiene. See E.J. Kibbleworth, "Mental Health Surveys in Alberta," unpublished Department of Health Paper, 1968, Premier's Papers, accession no. 69.289, Provincial Archives of Alberta. Most writers attribute this survey to Clarence Hincks, founder of the CNCMH. See McLaren, supra note 6 at 99 and Dowbiggin, supra note 10 at 179.

As quoted by Dowbiggin, ibid. at 179 . 
in connection with prevention, diagnosis, early treatment, control and follow-up supervision of mental abnormals. ${ }^{44}$

Compulsory medical attention for school children was not favoured by all, however. In her 1921 address, UFWA President Margaret M.L. Sears was sceptical of such a measure, in marked contrast to the views of her predecessor Irene Parlby. ${ }^{45}$ Sears warned that before the resolution was considered, delegates should ask what compulsory medical attention would mean to themselves, to their children, and to succeeding generations. She observed that:

Medical history, to date, proves conclusively that doctors are less sure of the truths pertaining to the healing of humanity than astronomers are of the truths of their science.... For the past quarter of a century the medical men have endeavoured by every means possible, to get legislation for some form of compulsory medical attention, on the books of nearly every English speaking country. ${ }^{40}$

Sears asserted that all people had the right to choose their own medical services. While she acknowledged the pressure on UFWA members to establish such reform, she stated that "one of my chief objects ... is to open your eyes to the great danger that may arise some time of being panic stricken and stampeded into granting medical legislation that will be a mill stone about the necks of succeeding generations." ${ }^{47}$

The enthusiasm with which many reformers greeted eugenic measures was not shared by all. Distrust of medicine and state intervention was at the root of many objections. Realizing this, reformers combined their campaign efforts. At the 1921 UFA convention, caring for the mentally deficient was the topic of an address by Dr. Shearer, "who made the meeting feel the necessity of institutional care of the feeble minded." facilities for the mentally deficient and to use "propaganda to mould public opinion." 49 It was at this conference that the first explicit reference to sterilization was made, in a resolution calling for the segregation of feeble-minded adults:

Whereas the problem of the feeble-minded is a continuous menace to society, and

Whereas the policy heretofore carried out in this Province deals only with the worst cases of mentally defective children, and

Whereas the real danger is constituted by the mentally defective adult;

Therefore be it resolved that we urge upon the Government the necessity of putting into operation as speedily as possible a plan whereby the adult mental defectives of both sexes may be kept under

Mental Hygiene Survey of the Province of Alberta, 1921, Premier's Papers, Accession No. 69.289, Provincial Archives of Alberta. Parlby left the UFWA executive ranks to become a Minister Without Portfolio in the UFA government in 1921. See Cavanaugh, supra note 15 at 95-97. United Farmers of Alberta, Annual Report and Year Book, 1921 [hereinafter UFA 1921] at 138. Ibid. at 139.

lbid. at 142.

lbid. 
custodial care during the entire period of reproduction. In this connection we would recommend that our women make a careful study of eugenics, with special reference to sterilization. ${ }^{\text {so }}$

The government's response to this resolution indicated that support was lacking for such a measure at this time:

The remedy for this, in the Government's opinion, lies in the last sentence of the resolution, but before such action could be taken, strong public sentiment in favour of it would have to be developed. ${ }^{\text {sI }}$

The UFWA membership was urged to make a study of the feeble-minded, "so that interest may be aroused in our women, helping us to realize our responsibilities one to another, especially to those who are weaker than we are." 52

Lobby efforts were increased in 1924. Of great significance in the campaign was an address given to the UFWA in January of that year by the Hon. Irene Parlby. ${ }^{53}$ In her lecture Parlby reported that the first step towards a solution of the "problem of the mental defective" was to educate the public to the seriousness of the situation and its effect on society. She identified the need for social leaders to awaken the public to solutions, as the public could not be forced to heed the counsel or to read the papers of "medical men." Seeing herself as such a leader, she used her address to inform the public that mental deficiency was highly hereditary, citing the authority of Dr. H.H. Goddard, a contemporary eugenicist whose study of feeble-minded families in the U.S. was often cited for its incredible statistics. ${ }^{54}$ She alerted the public to the fact that feeble-mindedness was closely associated with alcoholism, prostitution, venereal disease, and crime, ${ }^{55}$ and that the mentally deficient propagated their kind at a tremendous rate. ${ }^{56}$ She then outlined three remedies to the "problem" of the mental defective: regulation of marriage, segregation of all mental defectives, and sterilization. ${ }^{37}$

Parlby recognized that public sentiment was not yet in favour of any restriction of the marriage of the mentally and physically unfit and that attempts to persuade the population along this line had not yet met with success. She also related that the main obstacles to the segregation of the mentally unfit included the objections of naive, loving parents and the expense of caring for the great numbers of mental defectives in the province. Parlby described sterilization as "the great and only solution of the

Ibid. at 157.

"Government Reply to Convention Resolutions, 1922 by Minister of Municipalities and Health," File 168C, Premier's Papers, accession no. 69.289, roll 19, Provincial Archives of Alberta.

UFA 1921, supra note 46 at 142.

The Hon. Mrs. Parlby, Mental Deficiency: An Address Delivered Before the UFWA, January 1924 (Edmonton: Department of Public Health, 1924).

H.H. Goddard's book, The Kallikak Family (New York: MacMillan, 1931), originally published in 1912, was highly influential but by the mid-1920s, when Parlby was citing his work, Goddard was retracting most of his eugenic theories about the feeble-minded. See Dowbiggin, supra note 10 at $101,228$.

Supra note 53 at 5.

Ibid. at 4.

lbid. at $7 \mathrm{ff}$. 
problem." 58 Propagation would be prevented and the enormous burden placed on the taxpayer by these institutions would be avoided. She attributed the problem of legislating such a measure to "the difficulty of getting public opinion to support it, without long, long periods of education." 59

Parlby purported to leave the question of the extent of such a measure open to her audience and facilitated the discussion by presenting the arguments of two medical authorities. She articulated the views of a Dr. Tredgold who, while in favour of sterilization, did not advocate its wholesale application and suggested that segregation would still be necessary for the great majority. Dr. Goddard, on the other hand, viewed sterilization as a means to prevent the spread of "debauchery and disease," warning of the potential for the unsterilized to "gratify their instincts without fear of consequences, in the form of children." ${ }^{60}$ While Parlby claimed not to offer any personal opinions or recommendations, the language of her address, which described the dire consequences of non-sterilization, is evidence of her pro-sterilization stance. She urged that "as women, as mothers of the race, we should be considering this subject very seriously indeed." 61

Parlby's address was published in pamphlet form and distributed by the provincial Board of Health in 1924 to raise public awareness of the benefits of eugenic solutions for mental defectives. ${ }^{62}$ Availability of the address from the Home Service Secretary in Edmonton was also reported by The U.F.A newspaper, the mouthpiece of the UFA and UFWA organizations, a month after the address was given. The newspaper urged UFWA members to study the issue:

One of the most appalling questions before us is that of mental deficiency. Governments openly acknowledge that they are not yet ready to cope with the situation. Nothing can be done without the backing of an aroused, intelligent citizenship. Too long we have been content to continue ostrich-like, with eyes closed to this monstrous menace.... Surely here is a question for each Local to study.".

By the mid-1920s Alberta mental institutions were becoming overcrowded and the resulting increase in illness and violence was a growing concern. The death of an inmate of the Lethbridge jail in 1925 led to a call by Liberal MLA Nellie McClung for the investigation of all provincial institutions. As a result, a voluntary committee was set up to provide regular inspections. ${ }^{64}$ Prominent reformers were appointed to the

$\$ 9$

(1)

(6)

(1) Collins, supra note 6 at 94-95. Collins argues that the overcrowded conditions at the Ponoka,
Oliver and Red Deer facilities did not allow a curative program for mental deficiency to develop

Collins, supra note 6 at $94-95$. Collins argues that the overcrowded conditions at the Ponoka,
Oliver and Red Deer facilitics did not allow a curative program for mental deficiency to develop and so the focus in this period was on preventative work.

Ibid.

Ibid. at 11.

Ibid.

M. Combs, "The Support of Alberta Women for the Sexual Sterilization Act of 1928" (undergraduate history paper, University of Alberta, 1990) [unpublished, on file with author] at 10. This paper describes support of the UFWA for the Sterilization Act, but does not differentiate between the promotion of the act by elite UFWA reform leaders and the attitudes of the general UFWA membership, including farm women.

Supra note 33.

Ibid. at 10. 
Visiting Committee, including Police Magistrate Emily Murphy and Jean Field, VicePresident of the UFWA in charge of Public Health. ${ }^{65}$

\section{Concerns About InAdequate Facilities}

The pressing problems of inadequate facilities and the lack of money to improve them made eugenic measures more attractive, especially to those responsible for the Department of Health. In 1924, Minister of Health George Hoadley explained that "financial capacity, rather than desire, determined the policy of the Department" with respect to the problem of the mentally deficient. ${ }^{66} \mathrm{He}$ deplored the spending of thousands of dollars on mental defectives instead of those who would contribute something to society. ${ }^{67}$ The backing of the province's Minister of Health, one of the most influential members of the UFA cabinet, ${ }^{68}$ was critical to the ultimate passage of sterilization legislation. ${ }^{69}$ His opinion was shared by former Minister of Health, R.G. Reid, who articulated that viewpoint in a 1923 budget debate:

Should we provide institutional care for all mental defectives, with all the cost which it entails, or should we not consider the possibility of dealing with the matter in a more drastic way? ... Sometimes it is necessary and just that we should sacrifice sentiment to the greater interests of humanity ... this is the thought I would like to leave with you. ${ }^{70}$

Pressure for eugenic solutions and the issue of overcrowded facilities led Albertans to question the adequacy of care for the mentally ill. In the late 1920s, corresponding with the introduction and passage of the Sterilization Act, the government was asked to account for such incidents as the wrongful committal of a sane man to Ponoka, police mishandling of a deranged woman, theft by an Oliver Hospital employee, criticisms of the food provided at institutions, allegations of a Ponoka patient that she had suffered for two weeks with a broken wrist without receiving medical attention, and the death of a man committed to Ponoka who had been denied medical treatment during police incarceration. Criticism reached a peak in 1928, when a Ponoka patient, Dr.

Other members were also well-known reformers: Dr. J.M. MacEachern, chairman, was the head of the Department of Philosophy at the University of Alberta; Mr. W.J. Botterill was a well-known Red Deer businessman and community leader; and, Mrs. J.F. Anderson, also involved in the UFWA, was a respected church and community leader from Raymond. See S. Abercrombie, Alberta Hospital, Edmonton: 1923 to 1983 (Edmonton: Alberta Hospital, 1983) at 21. The U.F.A. (25 March 1924) 9.

67 The Edmonton Journal (24 February 1928).

(* Hoadley has been described as Premier John Brownlee's right hand man. He was acting premier whenever Brownlee was absent and was Minister in charge of Agriculture, the largest industry in the province. For more information on Hoadley's accomplishments in politics, see S.M. Kooyman, The Policies and Legislation of the UFA Government, 1921-1935 (M.A. Thesis, University of Calgary, 1981) at 14, 18.

The influence political leaders wielded with respect to sterilization legislation is evidenced by the successful opposition to sterilization in Ontario, credited to that province's deputy Minister of Health Dr. B.T. McGhie in the 1930s. See Dowbiggin, supra note 10 at 188. 
Hobbes, was beaten to death by an attendant after a force-feeding incident. This tragedy prompted Minister of Health Hoadley, after consulting with the Visiting Committee, to appoint a commission led by Dr. C.M. Hincks, Director of the Canadian National Committee for Mental Hygiene (CNCMH) and Dr. D.B. Farrar, head of the Toronto Psychiatric Hospital, ${ }^{71}$ to examine mental health problems in Alberta. ${ }^{72}$

The commission's report, tabled in February 1929, commented favourably on the work of the Visiting Committee and the good repair and cleanliness of Alberta mental institutions, but criticized the understaffed and overcrowded conditions, the mixing of different types of patients, and the inadequacy of admission, recreational, and medical treatment facilities. Recommendations included the abolition of force feeding, the removal of all mechanical restraining devices, and the erection of a new 1,500 bed facility. ${ }^{73}$

The appointment of Hincks and Farrar to the commission was evidence of the affiliation between the Minister of Health and prominent eugenicists. ${ }^{74}$ All three men were well-known advocates of sterilization. ${ }^{75}$ This relationship did not go unnoticed by contemporary critics who denounced as partisan the appointment of Hincks to the commission because of this mutual interest. ${ }^{76}$

Hincks' influence was not limited to Alberta political leaders. During the early 1920s, two visits by the CNCMH representative to Alberta and a series of addresses had considerable impact on members of the medical community and those prominently connected with social work in Alberta. " Hincks founded the CNCMH in 1918, inspired by the work of the U.S. National Committee for Mental Hygiene (NCMH). The $\mathrm{CNCMH}$, which enjoyed the backing of many of Canada's social, economic, academic, and professional elite, sought better treatment and prevention of mental disease and feeble-mindedness. The organization promoted eugenic solutions as a means to this end. ${ }^{78}$

For an analysis of Farrar's advocacy of sterilization, see Dowbiggin, supra note 10 at 185-86. Collins, supra note 6 at 96.

Ibid. at 97-98. A comprehensive analysis of the report's findings is found in Abercrombie, supra note 65 at $14-16$.

Hoadley's later position with the Study of Health Services Division of the CNCMH illustrates the strong connection he had with Hincks and that organization in the late 1920s. See December 13, 1939 correspondence between Hoadley, CNCMH, to William Aberhart, Premier of Alberta regarding the CNCMH report Distribution of Medical Care and Public Health Services in Canada, Premier's Papers, Accession No. 69.289, File 886, Provincial Archives of Alberta. In 1926, Hoadley asserted that the state must be protected from the menace of mental defectives, and that the province "should do everything in its power to see that as few as possible feebleminded people come into the world." Quoted from The Edmonton Journal (24 February 1926) in Lysne, supra note 6 at 101 .

"Assembly Adopts Resolution re Mental Hospital Unanimously After Amendment Defeated" The U.F.A. (15 March 1929) 20.

Abercrombie, supra note 65 at 9 .

For a treatise on the influence of Hincks and the work of the CNCMH, see Dowbiggin, supra note 10. See especially pages $168-71$. 
The campaign for sterilization in Alberta intensified in $1927 .{ }^{79}$ In her report to the UFWA as health convener that year, Mrs. Jean W. Field attempted to address many of the prevailing objections to sterilization. ${ }^{80}$ Countering arguments that sterilization was out of vogue, she predicted that sterilization legislation would soon be passed in British Columbia, described successful contemporary U.S. sterilization laws, and provided evidence of "keen interest" shown in Great Britain for such measures. She cited medical opinion to the contrary in response to the criticism that sterilization might increase prostitution and venereal disease, and advocated the establishment of a psychopathic hospital so that those whose mental disorders were caused by nervous breakdowns would not be housed in mental institutions and face sterilization upon discharge. ${ }^{81}$

Field was one of the most vociferous advocates of sterilization in the UFWA. Indeed, she has been credited with leading the organization in the campaign for sterilization legislation. ${ }^{82}$ Recognition of her concern in the area of mental health resulted in her appointments to the Visiting Committee of provincial institutions in 1925 and to the Eugenics Board in $1928 .^{83}$ The selection of such a well-known sterilization advocate to the Eugenics Board speaks to the agenda, influence, and close network of social reformers in Alberta during this time.

Field was joined in her lobby for sterilization by Judge Emily Murphy, another Visiting Committee member. In 1926, Murphy aided the sterilization cause by giving lectures on mental deficiency throughout the province. Her contention that "insane people are not entitled to progeny" was given widespread press attention. ${ }^{84}$ One writer has commented that Judge Murphy clearly helped create a climate of opinion in which sterilization became possible. ${ }^{85}$ Another prominent campaigner for sterilization was author, suffragist, and Liberal MLA Nellie McClung. McClung argued the hereditary nature of mental deficiency and the benefits of sterilization, especially for young, simple-minded girls. ${ }^{86}$ In her work The Stream Runs Fast: My Own Story, McClung described how sterilization had enhanced a young woman's life and contributed to the

79 See United Farm Women of Alberta, Reports and Addresses, 1927.

said. Ibid. at 23-29.

k1 Ibid. at 26-27.

"22 E. Carter, The History of Organized Farm Women of Alberla (Edmonton: United Farm Women of Alberta, 1954) at 32.

n3 To implement the provisions of the Sterilization Act, the Minister of Health appointed a eugenics board made up of Dr. Edgerton Pope, University Hospital; Dr. Mason, Calgary; Dr. MacEachern, Ph.D., University of Alberta, and Mrs. J.W. Field, Spurfield. UFA 1929, supra note 13 at 30-31. Dr. MacEachern had also been appointed to the Visiting Committee in 1925. Combs, supra note 61 at 12.

As quoted in Christian, supra note 4 at 10-12. A concise analysis of Murphy's influence on the law is presented by J. McLaren, "Emily Ferguson Murphy, (1868-1933) in R.M. Salokar \& M.L. Volcansek, eds., Women in Law (Westport, Conn.: Greenwood Press, 1996) at 190-201. Murphy's assistance in the British Columbia campaign for sterilization is well-documented by McLaren, supra note 6 at $100-102$.

Foster, supra note 6 at 148 . 
happiness of her family. ${ }^{87}$ McClung's public backing of sterilization is documented as being vital to the success of eugenic legislation in Alberta. ${ }^{88}$

In 1928, UFWA President Margaret Gunn remarked that, while the question of the mental defective continued to present a grave problem, the situation was appearing more hopeful:

For with greater interest and greater intelligence being brought to bear on the subject, the possibilities and responsibilities attaching to the community and Province are coming more clearly into position. ${ }^{89}$

However, that the campaign had not reached many of the UFWA members was commented on by UFWA Health Convener Jean Field a few months earlier, as she stated that she had received "many enquiries from UFWA members as to the purpose of the Sterilization Act" which had been introduced into the Legislature that year. ${ }^{90}$ In her November 1927 health bulletin Field provided details of the proposed legislation and advanced familiar defences of sterilization. She concluded with an offer to answer any questions anyone still had and with the hope that:

[T]he members of all our U.F.W.A. Locals will give thoughtful and unprejudiced consideration and study to this important question. The Minister of Health has had the courage to introduce the bill into the Legislature and you can help by sending a resolution or letter expressing your approval of the step which has been taken, sending a copy to your own local member of the Legislature as well. ${ }^{91}$

The 1928 UFWA Convention Report stated that a sexual sterilization bill had been given first reading in the Alberta legislature in 1927, and that the Minister of Health desired that the bill be given wide publicity and careful study. It was recommended that each local secure a copy of the bill and after serious discussion, send in their approval or disapproval in the form of a resolution to the Minister. ${ }^{92}$ Throughout the summer of 1927, UFWA leaders lobbied for sterilization legislation in speaking tours throughout the province. ${ }^{93}$ The U.F.A. helped spread the message by printing such articles as "The Problem of the Feeble Minded," 94 and "Alberta Is Giving Dominion Leadership in Mental Hygiene."'s

\section{Vili. The Passage of The Sterilization act}

The commotion that greeted the sterilization bill in 1928 in the Legislature, in the public arena, and in the press was evidence of continuing reservations about sterilization despite more than ten years of lobbying by reformers for the measure. On

(Toronto: T. Allen, 1945). As quoted in McLaren, supra note 6 at 100.

Ibid. at 94.

UFWA 1928, supra note 27 at 4.

Ibid. at 28.

The November 1927 health bulletin was reprinted in the 1928 Annual Report. Ibid. at 28-30.

lbid. at 35 .

See The U.F.A. (15 July 1927) 30.

The U.F.A. (1 June 1927) 22.

The U.F.A. (15 September 1927) 16. 
March 7, 1928, The Edmonton Journal recorded that the "drastic" bill had been given third reading "but only after one of the stormiest passages that any measure before the Alberta house has been accorded in recent years." 96 The Edmonton Bulletin also reported the passage of the Sterilization Act after "weathering one of the most severe storms ever given a bill in the provincial legislature." 97 From the first introduction of the sterilization bill in 1927 to its final enactment on March 21, 1928, press coverage of the proposed legislation was extensive.

\section{THE QUESTION OF SUPPORT}

Hesitancy on the part of the UFA government to introduce the sterilization measure was reflective of the contemporary controversial nature of eugenics and concern over public support. It was first introduced in March 1927 but not discussed past second reading. Hoadley stated that "while personally he thought the measure should be pushed through, at the present time the government had not yet made up its mind on the matter." ${ }^{98}$ The bill was allowed to remain on the order paper to allow public interest to be directed to the bill and so that it would be "sufficiently discussed before the next session of the legislature for the government to decide whether to enact the legislation or withdraw it at that time." 99 That the measure was not presented as part of the session programme in the 1928 Speech to the Throne address is further indication the UFA government was still unsure of its sterilization proposal at this late date. Premier Brownlee's own admission of misgivings when the bill was first proposed is testimony to the government's lack of enthusiasm for sterilization. He recounted that "[w]hen the bill was first drawn to his attention in executive council he had received it with anything but enthusiasm." 100

After second reading of the sterilization bill in 1928, The U.F.A. printed an editorial which questioned support for the measure:

It cannot fairly be said that time has not been given for the public to acquaint itself with the provisions of the bill, of which Mr. Hoadley is sponsor, though it may be questioned whether public opinion has been crystallized on the subject.... [W] Wen a new principle is involved, especially, legislation should be the carrying into effect of what Lord Haldane has described as the "General Will." Has the "General Will" as yet been evoked? Upon this point there may be room for doubt. We are not sure. ${ }^{101}$

UFA and UFWA members were among those who denounced sterilization in 1928. Prominent among the voices raised in opposition to the bill in the Legislature was that of Laudas Joly, the UFA MLA from St. Paul. Although his objections were

\% 1928).

$\boldsymbol{9}$

"Sexual Sterilization Bill Receives Third Reading in House" The Edmonton Journal (7 March

"Sterilization Bill Passes Third Reading" The Edmonton Bulletin (7 March 1928).

"Sterilization of Defectives Before House" The Edmonton Bulletin (26 March 1927).

"Liberal Leader to Question Sterilization Bill Validity" The Edmonton Bulletin (29 March 1927).

"Sterilization Bill Proceeds to Committee" The Edmonton Bulletin (25 February 1928). Mr.

Brownlee "confessed that at the beginning he had strong feelings against treatment of this nature."

"Second Reading Given Sterilization Bill in the Legislature" The U.F.A. (1 March 1928) 30.

"Editorial" The U.F.A. (1 March 1928) 3 and 7. 
comprehensive, perhaps his greatest reservations were religious in nature. ${ }^{102}$ Rice Sheppard, one of the founders of the UFA, was a member of the People's Protective League, an organization two hundred members strong, which had been formed to test the constitutionality of the Sterilization Act on the ground that it interfered with individual rights. ${ }^{103}$ The League met with the Premier and Cabinet the day after the Sterilization Act passed to protest its enactment. ${ }^{104}$ Objections of UFWA members included a letter sent by the Pleasant Valley UFWA Local to the Minister of Health in July 1927, registering their disapproval of the Act. ${ }^{105}$ And, two months before The Sterilization Act became law, the Camrose UFWA local submitted the following resolution at the UFWA Convention:

\begin{abstract}
Whereas, seventy-two per cent of the patients in the mental hospitals of this Province were not born in Canada, and

Whereas, physical fitness should occupy a place second to that of moral fitness in regard to marriage, and

Whereas, under appropriate supervision and patient guidance the higher grades of feeble minded may become in a limited measure self-supporting, and

Whereas, sterilization constitutes a violent and drastic invasion of the most elementary human rights and does not take away the sexual desire, and still leaves the patient utterly lacking in moral resistance, and leaving them a prey to the dangers of social contact with people of low moral standards,

Therefore, be it resolved that the Camrose Local of the U.F.W.A. are opposed to the said Sexual Sterilization Act and urge upon our Provincial Government a measure of "segregation" of the feeble minded of this Province. We advocate the help obtained in financing this by elimination (sic) undesirable immigration, by making marriage laws more strict and proper supervision and education, making the mental defective partly self-supporting. ${ }^{\text {.1xi }}$
\end{abstract}

It is clear that many proposed reforms directed at solving the problem of mental defectives were viewed as eliminating the need for eugenic solutions. Reforms such as segregation, controlled immigration, compulsory medical inspection of school children, ${ }^{107}$ education, supervision, and health certificates before marriage, ${ }^{108}$ while

Among his many arguments against the bill, Joly maintained that procreation was a divine right which ought not to be conceded to the state. His speech received a loud ovation. See "Bill to Sterilize Unfit Debated in the Legislature" The U.F.A. (1 March 1928) 16. Joly's Roman Catholic beliefs have been identified as the root of his opposition. See Collins, supra note 6 at 89 .

103. See "Geo. Hoadley's Sterilization Bill Fought" The Calgary Herald (8 March 1928) and "Sterilization Measure Meets Some Opposition" The Lethbridge Herald (8 March 1928). Both articles identified that prominent members of the league also included J.W. Leedy, a former governor of Kansas and Rev. J.F. Knight of Westmount Church. "Delegation Waits on the Government re Sterilization Bill" The U.F.A. (15 March 1928) 33. See "Letter to Minister of Health," July 7, 1927 signed by C. H. Zackzkowski, Secretary. Premier's Papers, Accession No. 69.289, Provincial Archives of Alberta.

"Resolutions for the Annual Convention" The U.F.A. (16 January 1928) 5.

Inspection of school children was first advocated by reformers in the UFWA in 1917, and was the subject of resolutions in the years 1918 through to 1921 and in 1928. See United Farmers of Alberta, Annual Report and Yearbook, 1917-1921 and United Farm Women of Alberta, Reports and Addresses of the Annual Convention, 1928. 
promoted by sterilization supporters as adjuncts to eugenic measures, were considered by those opposed to sterilization as suitable alternatives. ${ }^{109}$

\section{The Debate}

The controversy that greeted the sterilization bill in 1928 reflected the full range of contemporary debate over this eugenic measure. A delegation of citizens approached Hoadley a week before the bill's passage with the concern that all inmates would to be subjected to sterilization. ${ }^{110}$ Concern was expressed about the possibility of sterilizing temporary or wrongfully-admitted patients." advanced on religious grounds. ${ }^{1 / 2}$ Another argument was that sterilization breached individual rights: that an individual considered sane enough to leave an institution had to choose between sterilization or remaining in that institution was considered a trespass on individual liberty. ${ }^{113}$ Premier Brownlee's response reflected the social reform attitude that the good of society trumped the good of the individual:

The belief that an Englishman's home was his castle no longer held good in view of changing conditions of democracy and where the good of the State was concerned the right of the individual had to yield place. ${ }^{114}$

Health certificates before marriage was first proposed by the UFWA in the years 1918-1920, and was also the subject of resolutions in the years 1925, 1929, 1932 and 1933. See United Farmers of Alberta, Annual Report and Yearbook, 1918-1920, United Farmers of Alberta Addresses and Reports Presented to the UFA Convention, 1925 \& 1929, and United Farm Women of Alberta, Reports and Addresses of the Annual Convention, 1932-1933.

Two concurrent campaigns appear to have existed with regard to mental defectives: limitation of their numbers by sterilization, and control over their sexuality by such means as segregation and marriage laws. Supra note 97.

At the 1929 UFWA convention, a resolution calling for the establishment of a psychopathic hospital for those suffering from temporary mental distress was passed, in response to protests about the housing and treatment of minor mental ailments with more severe cases of mental deficiency, and the consequent fear that those suffering such temporary ailments would be subject to the same sterilization criterion as more serious, permanent cases upon discharge from mental institutions. See UFWA 1929, supra note 13 at 51.

112 See the objections of Joly, supra note 100. In a letter to the editor of The Edmonton Journal, Tillie Phelan wrote: "Sterilization: ... It is with profound horror that I note the discussion of this in the house. I am sure if St. Paul were alive today this word would be added to his list of 'Let it not be so much as mentioned among you as behoveth saints.' Just where in the Old or New Testament does God give man power over the bodies of His afflicted!" The Edmonton Journal (26 February 1928).

113 Such were the comments of Liberal MLA, L.A. Giroux. "Sterilization Bill Given Second Reading; Opposition is Strong" The Edmonton Journal (25 February 1928). In a letter to the editor of The Edmonton Journal, Malcolm MacCormick asserted: "And finally, freak legislation and impertinent, meddlesome laws, that infringe upon the just rights and proper domain of the individual, have been, for the past quarter of a century, the bane and moral weakness of Canada." The Edmonton Journal (26 February 1928).

"Government Faces Solid Opposition" The Calgary Albertan (25 February 1928). 
The social reform movement defended its increasing intervention in the lives of the sick, immigrant, indigent, young, and mentally ill on the ground that such intervention would result in a better and more prosperous society. ${ }^{115}$

Those opposed to sterilization also proposed that it interfered with the federal government's power to legislate. Liberal Leader Captain Joe Shaw questioned the validity of the sterilization bill in 1927 on this basis, suggesting that it was "outside the jurisdiction of the provincial government, and comes under the provisions of the Criminal Code of Canada, and is therefore a matter for Federal government to deal with." 116 He was not the only one who believed sterilization may fall under the federal government's criminal law jurisdiction. A 1926 UFA resolution called for the Government of Canada to amend the Criminal Code to provide for operations on mental deficients. The federal Minister of Justice responded that he "hardly thinks such a recommendation could be accepted at present, but will give it consideration." 117 Concern about infringing upon the jurisdiction of the federal government led the UFA government to solicit the opinions of O.M. Biggar, K.C. and E. LaFleur, K.C. on the constitutionality of the sterilization bill. Both opined that the bill was within the jurisdiction of the Alberta Legislature, under s. 92(13) of the B.N.A. Act, 1867 (property and civil rights). ${ }^{118}$

Perhaps most striking in the opposition to sterilization was the fear that such a measure would produce a dangerous spread of immorality. The impact of sterilization on women was most feared: "If feeble-minded women were treated at the mental institutions and then turned loose upon the community, they would prove a menace and social evils would be almost sure to follow."119 In addressing this concern, Premier Brownlee also linked mental deficiency to moral degeneracy. Admitting that there was the danger of a certain amount of "evil springing up," he asserted that "this was likely to happen in any case." 120 Concern for sterilization's impact on social mores was advanced most forcefully by a concerned citizen:

Improving the human race, and trying to avoid deterioration are worthy of our best efforts. What is the chief cause of physical and mental deficiency and moral delinquency[?] Sexual depravity, which sterilization tends to increase. ${ }^{121}$

That insufficient time had been given to hear opinions was also an objection advanced in 1928, but this argument was dismissed on the basis that sterilization had been raised

\footnotetext{
IIs Valverde, supra note $10, \mathrm{c} .1$.

$116 \quad$ Supra note 99.

117 "Secretary of UFA Parliamentary Group Presents Report on the Action Taken Respecting Convention Resolutions" The U.F.A. (15 July 1926) 9. Sessional Paper No. 48, 1928, Accession No. 70.414, File 920, Provincial Archives of Alberta. This argument was advanced by Giroux, supra note 113.

The Medicine Hat News (25 February 1928).

Letter from J. Galloway to the Minister of Health cited in "Opponents of Sterilization Busy in House" The Edmonton Bulletin (6 March 1928).
} 
on several occasions by the UFA government and that a sterilization bill had been introduced in the 1927 session of the House.

Sterilization was also resisted on the basis that medical and scientific opinion was inconclusive on the issue. In the 1920s new scientific "truths" altered the focus of the mental hygiene movement. The ideas of hereditary determinism, closely associated with eugenic principles, were challenged by scientific research into environmentalism and genetics. By 1927 when the UFA first introduced its sterilization measure, the "nature/nurture" debate had already peaked in the United States and eastern Canada. The scientific voices of behaviourism and environmentalism were in ascendency, while Galtonian eugenicists were in retreat. In 1929 S.P. Davies commented that the "hasty generalizations of a decade ago had produced a grossly overdrawn 'social indictment' of the mentally defective." 122 An article in the British Medical Association Journal in 1928 concluded that "for the purpose of eradicating or preventing the spread of mental deficiency, the sterilization of a small number of feeble-minded persons would be ineffective." 123

The medical and scientific communities were reconsidering their support for sterilization by the late 1920s. An editorial in the Canadian Medical Association Journal (CMAJ) in November 1928 commented that while the American Medical Association recognized the widespread interest in sterilization legislation, it believed "the medical profession has not given the subject the study it deserves." 124 In the same year, the CMAJ expressed misgivings about Alberta's new sterilization legislation, doubting that sterilization would become widespread and voicing concern about criminal liability and the infringement of individual liberties. ${ }^{125}$

Arguments raised in opposition to the sterilization bill in Alberta reflected an awareness of the changing scientific and medical perceptions of the mental hygiene movement. Members of the Legislature who opposed the bill repeatedly proposed that the House "obtain the best possible medical opinion in the country as to its advisability." 126 One critic "quoted many authorities against sterilization ... he urged the house to be careful and not to embark on an unexplored sea until the word of outstanding authorities on both sides of the question had been obtained." 127 Those in support of the bill cited medical and scientific opinion which was increasingly controversial. In fact, Premier Brownlee "frankly admitted there was no use denying that scientific opinion was at

Cited from his work Social Control of the Mentally Defective in K. McConnachie, Science and Ideology: The Mental Hygiene and Eugenics Movements in the Interwar Years, 1919-1939 (Ph.D. Dissertation, University of Toronto, 1987). McConnachie chronicles the split in the CNCMH in the 1920s due to the declining popularity of early eugenic theory. Her thesis documents the growing antagonism towards sterilization in the late $1920 \mathrm{~s}$. This April 1928 article from the BMAJ was cited in "Inheritance of Mental Defect" (August 1928) 19 CMAJ at 251. "Editorial Comments" (November 1928) 19 CMAJ at 586.

"Medical Legislation" (May 1928) 18 CMAJ at 613.

"Hoadley Sterilization Bill Occupies Attention of the Legislature" The Medicine Hat News (24 February 1928).

127 Arguments of Col. Weaver, Conservative MLA in "Sterilization Bill Given Second Reading; Opposition is Strong," supra note 113. 
variance on the subject, but that the trend now was toward crystallization in favour of the action advocated in this bill." 128 Those opposed argued that "scientists have not definitively proved that a feeble-minded person can transmit mental characteristics," especially in cases where feeble-mindedness was caused by disease and was not hereditary. ${ }^{129}$ Objections to sterilization legislation must be understood in the context of a period in which scientific management and professionalism were increasingly valued. Endorsement of sterilization was sought from the medical and scientific communities to validate the passage of the bill. ${ }^{130}$

The influence of the United States was certainly a factor in the Alberta sterilization debate. Early progressive ideas concerning the impact of large numbers of feebleminded persons on the economic and social order had filtered across the border to the western provinces. The influence of American eugenic ideas on Alberta is evidenced by the use of that country as a standard in arguments both for and against sterilization; the great number of states possessing sterilization legislation was often cited by the Minister of Health in support for his bill, while opposition forces countered with the observation that in many states, such legislation was either a dead letter, considered experimental, or under repeal. ${ }^{131}$ The 1927 U.S. Supreme Court decision in Buck v. Bell, ${ }^{132}$ which upheld the constitutionality of a State of Virginia statute providing for sterilization of mental defectives, had a positive influence on the pro-sterilization debate in Alberta. ${ }^{133}$ The court decision provided judicial backing for sterilization at a time when scientific and medical support for eugenics was on the decline. Justice Holmes articulated conventional moral and hereditary arguments in favour of sterilization:

It is better for all the world, if instead of waiting to execute degenerate offspring for crime, or to let them starve for their imbecility, society can prevent those who are manifestly unfit from continuing their kind. The principle that sustains compulsory vaccination is broad enough to cover cutting the Fallopian tubes.... Three generations of imbeciles is enough. ${ }^{34}$

\section{ECONOMIC CONCERNS}

In the late 1920s, the UFA government sought to relieve the pressure for better, more accessible health care and for economic reform. Public concern about the deficit was expressed during the same period that sterilization was debated. In its announcement of public debt increases of over $\$ 26$ million, The Medicine Hat News contended that

"Sterilization Bill Proceeds To Committee," supra note 100.

See the arguments of Giroux, supra note 113.

By the early 1920s, eugenicists such as Goddard were retracting most of their eugenic theories about the feeble-minded. See Dowbiggin, supra note 10 at 228.

See the February 24, 1928 editions of The Edmonton Journal, The Lethbridge Herald and The Medicine Hat News. Later in the session, Hoadley acknowledged that the New York legislation had been repealed because it had been found unconstitutional; this did not deter him however. The Edmonton Journal (6 March 1928). 274 U.S. 200.

Institute of Law Research and Reform, Sterilization Decisions: Minors and Mentally Incompetent Adults, Report for Discussion No. 6 (Edmonton: Institute of Law Research and Reform, 1988) at 28.

Ibid. 
the government's response should be not to increase taxation but to curtail expenditures. ${ }^{135}$ In defence of his sterilization bill, Hoadley declared his concern for the economic future of the province: "Hundreds of thousands of dollars were being spent on this class of people that would be far better spent on the well."136 Sterilization offered a solution to the problem of overcrowding at mental institutions in Alberta. One study of the bill correlated the numbers of patients sterilized to the level of overcrowding and concluded that when the numbers of cases admitted to Alberta mental institutions levelled out, so too did the numbers presented to the Eugenics Board for sterilization. ${ }^{137} \mathrm{~A}$ contemporary reformer commented on the economic rationale:

We cannot segregate the feeble-minded because of the enormous expense this would entail. But when we read of ... the enormous expense they cause the state through crime, pauperism, drunkenness and disease at a cost to the state of millions of dollars annually, we must realize the need for preventive measures. ${ }^{138}$

Premier Brownlee's support for sterilization hinged on economic factors:

...he looked around for a solution and found only two alternatives -segregation or sterilisation [sic]. Either case meant interference with the rights of the individual. Segregation would have to be done at the expense of the state, already burdened to capacity. The other alternative was his choice. ${ }^{139}$

In 1928, the economic difficulties facing the province were related: "The public health vote can not be kept up, the insane must run at large,' or we may say that we cannot expend the money that we have expended in the past for our public roads." 140 The potential curtailment of health expenditures was described by Premier Brownlee:

Such absolutely necessary things as health, psychopathic hospitals and other things of that nature had to be delayed, and the interim budget would show a deficit which might or might not be made up before the end of the year in March. These things gave him considerable anxiety. ${ }^{141}$

During the debate on the sterilization bill, Attorney General Lymburn acknowledged that if the question was purely academic, he would have to agree with the arguments of UFA Member Laudas Joly against sterilization. And if the question was purely technical, he would agree with the demand to go slowly, but an alarming increase in the population of Alberta's mental hospitals "meant that accommodation would have to be increased and heavy yearly expenditures incurred to cope with this increase. The solution lay in a measure of this kind." 142

\footnotetext{
135 “Another Alta. Deficit" The Medicine Hat News (25 February 1928).

136 The Edmonton Journal (24 February 1928).

137 Clarke, supra note 5 at 159-60.

13n "The Problem of the Feeble-Minded," supra note 94.

139 Supra note 100.

$140 \quad$ The U.F.A. (9 February 1928) 16.

141 "Railways, Old Age Pensions Budget and Bill to Provide for Sterilization of Mental Defectives Debated by Assembly" The U.F.A. (1 March 1928) 13.

142 "Second Reading Given Sterilization Bill in the Legislature," supra note 100 at 29.
} 


\section{Final Reading}

Third reading of the sterilization bill was passed close to midnight on March 7, 1928 after two amendments were voted down. The first amendment called for a six months delay of the bill, while the second amendment sought to increase the membership of the board from four to five and to require that two members of the board be qualified female medical practitioners. ${ }^{143}$ The bill finally passed third reading by a vote of 31 to 11. All UFA members present and three Labour MLAs voted in favour, while all Liberal and Conservative Members, along with two Labour MLAs voted against. That the issue divided UFA Members is confirmed by the absence of 13 Members, including Joly and A.M. Matheson who had earlier tried to have the debate adjourned. UFA Member M.J. Connor abstained. ${ }^{144}$

In response to a request for the names of organizations and individuals supporting the sterilization bill, a list of prominent individuals and associations who were in favour of the legislation was tabled in the House. Three UFA locals and 10 UFWA locals were listed, as well as such familiar names as Emily Murphy, Dr. C.M. Hincks, and Dr. C.B. Farrar. ${ }^{145}$ However, while the Edmonton Local Council of Women had sent a resolution in 1922 to the Minister of Health calling for sterilization of the feebleminded, ${ }^{146}$ its support of the bill in 1928 was conspicuously lacking. This was likely due to the reservations of their parent body, the National Council of Women, which had resolved in November 1927 that it was not prepared to agree with the sterilization of the feeble-minded without further knowledge on the subject. ${ }^{147}$ The silence of the Edmonton Local Council of Women was representative of the growing uncertainty about the validity of sterilization in this period. Unequivocal support from such bodies as the College of Physicians and Surgeons, the Imperial Order of Daughters of the

"Sterilization Bill Finally Adopted in House" The Edmonton Bulletin (7 March 1928).

Sec Foster, supra note 6 at 149 and "Effort Made to Delay the Sterilization Bill Proves Unsuccessful" The U.F.A. (15 March 1928) 13. Of course, Brownlee, Hoadley and Parlby were recorded as voting in favour of the bill. The extent of ill-feeling against the bill in some quarters was shown by the pasting of stickers in shop windows along Jasper Avenue the night before the bill received third reading, calling for the sterilization of Hoadley. These stickers were also sent to most members of the Legislative Assembly. See "Effort Made to Delay the Sterilization Bill Proves Unsuccessful," ibid., and "Around the Corridors" The Edmonton Journal (7 March 1928). Foster writes that the stickers were pasted during the night after the bill received third reading. Sec Foster, supra note 6 at 149.

Support for the bill was given by the Edmonton branch of the Canadian Social Hygiene Council and the women's section of the Dominion Labour Party, Calgary. Personal endorsements of Alberta residents were sent by: Rev. Thos. H. Mitchel, Robertson Church, Edmonton; Mrs. Emily Murphy, Police Magistrate; Dr. Geo. R. Johnson, Registrar of the College of Physicians and Surgeons, Calgary; Mrs. O.O. Edwards, Chairman of the Provincial Executive Committee, Council of Women; and, Mrs. L.C. McKinney, Alberta Provincial Women's Christian Temperance Union. Other endorsements were sent by Dr. C.M. Hincks and D.M. LeBourdais of the CNCMH and Dr. C.B. Farrar, Superintendent of the Psychopathic Hospital in Toronto. Four supporters from various locations in Canada and the United States were also identified. "Sterilization Act Has Much Backing" The Edmonton Journal (9 March 1928).

This resolution, dated February 23, 1922 is included in the Sessional Papers of the Legislative Assembly, Accession No. 70.414, Provincial Archives of Alberta.

The Edmonton Journal (6 March 1928). 
Empire, and the provincial Women's Christian Temperance Union was also notable in its absence. ${ }^{148}$

\section{CONCLUSION}

Although by 1928 medical and scientific support for eugenics was waning, the united efforts of certain members of Alberta's social, political and medical elite, combined with the problems of inadequate mental facilities and underfunding, ensured the passage of Canada's first sterilization legislation. Eugenic reform was part of a larger social reform movement in Canada in the early twentieth century. The impact of immigration, industrialization and urbanization caused concern about the degeneration of Canadian society. Eugenics appealed to members of the middle and upper classes who focused their efforts on the indigent, immigrant, and mental defective populations.

In Alberta, the agenda of reformers was revealed through their efforts in the UFWA, where they lobbied for sterilization from 1916 to 1928 . The length of time it took for such a measure to become law reflected the uncertainty with which sterilization was viewed in the province. This is evidenced by the lack of unified support for the Sterilization Act in the UFA government and in the UFA and UFWA organizations. Debate in the Legislature and media coverage surrounding the passage of the sterilization bill is also revealing of contemporary reservations. Notwithstanding such opposition, the lobby for sterilization in Alberta met with success, due largely to the mutual efforts of reformers, whose eugenic ideas were made more palatable by the pressing problems of inadequate mental facilities and budgetary concerns in the late 1920 s. $^{149}$

The ultimate decline of the eugenics movement in Canada has been attributed to the outbreak of World War II and the denunciation of Hitler's use of sterilization as a measure to purify the German population. ${ }^{150}$ Though the reputation of eugenics in Canada would be badly damaged by 1940, the effects of such ideas continued to affect individuals in Alberta for at least 30 years. Amendments to the Sterilization Act in 1937 expanded criteria for sterilization to include risk of mental injury to inmates or to their progeny. Consent was still required for psychotic cases, but was eliminated for mental defectives. $^{151}$ In 1942 , the powers of the board to authorize sterilization were expanded to cases of neurosyphilis, epilepsy with psychosis or mental deterioration, and Huntington's Chorea. Consent was required in these cases except for a person with Huntington's Chorea who was also psychotic. ${ }^{152}$ The Sterilization Act was not repealed until 1972. ${ }^{153}$

14x "Sterilization Act Has Much Backing," supra note 145.

149 Dowbiggin describes the role of sterilization as "key to a policy of deinstitutionalization which might solve the chronic problems of overcrowding and underfunding." See Dowbiggin, supra note 10 at $182-83$.

(s) Ibid. at 187

151 The Sexual Sterilization Amendment Act, S.A. 1937, c.47.

152 The Sexual Sterilization Amendment Act, 1942, S.A. 1942, c. 48.

153 The Sexual Sterilization Repeal Act, 1972, S.A. 1972, c. 87. 
The persistence of the Sterilization Act on the Alberta statute books was remarkable. Any objections to the 1937 and 1942 amendments were muted. In 1937, brief newspaper coverage was given to the details of the amendment and to the attempts to stall the legislation, but it passed "with only Liberal voices raised in opposition." 154 In 1942 The Edmonton Journal only printed a brief synopsis of the amendments. ${ }^{\text {iss }}$ Reasons for these silent extensions of power and the failure to repeal the Sterilization Act until 1972 are questions which demand further study.

The recent Alberta Court of Queen's Bench decision in Muir v. Alberta, ${ }^{156}$ in which the Court found the province liable for the wrongful and deliberate sterilization of a former mental institute patient, raised the issue of sterilization seventy years after it was first debated in the province. In March 1998, the Alberta government attempted to introduce legislation to restrict compensation to approximately seven hundred outstanding cases of individuals wrongfully sterilized under the Sterilization Act to a maximum of $\$ 150,000$ per person. The government proposed protecting the restriction by invoking s. 33 of the Charter of Rights and Freedoms (otherwise known as the notwithstanding clause) to exempt it from the constitutional guarantee of rights and freedoms. The amount of public criticism the proposed legislation generated caused the Alberta government to withdraw the bill. ${ }^{157}$

Current debate about Alberta's Sterilization Act mirrors the reservations expressed about sterilization in the 1920s. The fear that wrongfully admitted patients would be sterilized was realized, as in the case of Leilani Muir. The Sterilization Act's contemporaries also objected to sterilization on the grounds that it trespassed on individual liberties and that sterilization no longer accorded with medical and scientific theories about the mentally deficient, arguments which formed the basis for the repeal of the act in $1972 .{ }^{158}$ Although the implementation of sterilization in the early years of Alberta reflected that society's particular realities, mores and attitudes, many of the objections to sterilization in that period foreshadowed views about medicine, human rights and the law which are espoused today.

"From the Gallery" The Calgary Albertan (6 April 1937). See also "Consent Needed" The Calgary Albertan (17 March 1937) and "Sterilization Debate Bares Bad Condition" The Edmonton Bulletin (1 April 1937).

iss "Sterilization Act Force Broadened" The Edmonton Journal (6 April 1942).

156 Muir v. Alberla (1996), 36 Alta. L.R. (3d) 305 (Alta. Q.B.).

157 The notwithstanding clause has only been used twice by provincial Legislatures: once by Saskatchewan in the 1980s to legislate striking workers back to work and once in Quebec to protect language legislation. See "Klein Retreats in Rights Scrap" The Globe and Mail (12 March 1998) AI. See also "About Face" The Edmonton Journal (12 March 1998) Al, A5. Alberta Hansard, supra note 4 at 58-35 to 58-37. 